青山万理子，三好 孝典，井上 聖也

日野 直樹, 露口＼cjkstart勝

\begin{abstract}
要旨
肺葉内分画症に対し，胸腔鏡下肺葉切除術を施行し，良好な結果が得られた 1 例を経験したので，報告する.

患者は 30 歳, 男性. 幼少時より胸部異常陰影を指摘されていたが, 特に症状を認めず放置していた。発熱，関節痛，全身 倦怠感を自覚し, 前医を受診した，精査の結果，肺葉内分画症とその部位の肺化膿症と診断され，治療目的に当院へ紹介と なった，MEPM の投与を行い症状の改善を認めたが，胸部 CT で膿㿎腔は残存しており，手術の方針とした，術前造影 CT では, 胸部下行大動脈から左横隔膜に接して分画肺へと繋がる血管を認めた，術式は，胸腔鏡下左肺下葉切除を選択した. 発症より 20 日目に施行し，術後 10 日目に退院となった.

肺分画症に対し，胸胿鏡下肺葉切除を安全に施行することが出来た。また，初回感染発症後，早期の外科的治療は根治的 治療として非常に有効であると考えられた。
\end{abstract}

索引用語：肺葉内分画症，胸胿鏡下手術

intralobular pulmonary sequestration, thoracoscopic surgery

\section{はじめに}

肺分画症は，正常気管支と交通がなく，大循環系から の異常血管により還流される隔離された異常肺組織を持 つ疾患である.なかでも肺葉内分画症は, 8 割が分画肺へ の反復感染を呈し, 治療として外科的切除が基本とされ ている. 今回我々は, 肺化膿症を発症した肺葉内分画症 に対し胸腔鏡下左下葉切除を施行し, 良好な治療経過を たどった 1 例を経験したので報告する.

\section{症例}

症 例 : 30 歳, 男性.

主 訴：発熱, 全身倦急感, 関節痛.

既往歴：30 歳時に大腸憩室炎.

家族歴：祖父，気胸.

喫煙歴：喫煙指数 $100 （ 10$ 本 $/$ 日 $\times 10$ 年).

徳島市民病院外科

原稿受付 2014年 3 月 8 日

原稿採択２014年 7 月31日
現病歴：幼少時より胸部 X 線像での異常陰影を指摘 されていたが, 特に症状を認めず放置していた. 8 力月前 に大腸㮩室炎を発症し，その際の CT 検査で下行大動脈 から左胸腔内に向かって分岐する異常動脈を認め，肺葉 内分画症の可能性を指摘された (Fig. 1). 発熱, 関節痛, 全身倦急感を自覚し, 発症より 3 日目に前医を受診した。 精査の結果, 肺葉内分画症と分画肺の肺化膿症と診断さ れ，治療目的に発症 6 日目に当院へ紹介となった.

入院時現症：身長 $177 \mathrm{~cm}$, 体重 $89 \mathrm{~kg}$, 体温 $38.4^{\circ} \mathrm{C}$, SpO2 96\% (room air), 聴診で左下肺野の呼吸音減弱を認 めた.

入院時血液生化学所見：WBC $16,700 / \mu \mathrm{l}, \quad$ CRP 14.8 $\mathrm{mg} / \mathrm{dl}$ と炎症所見を認めた。

入院時胸部 $\mathrm{X}$ 線像：左下肺野に浸潤影を認めた（Fig. 2).

前医造影 CT：左肺底部に囊胞性変化を伴う液体貯留 を認め，肺化膿症による炎症像であった（Fig. 3a）。

入院後より Meropenem $(\mathrm{MEPM}) 1 \mathrm{~g} \times 3$ 回/日投与を 開始し, 発症 8 日目に解熱し, 発症 16 日目には血液検査 での炎症反応正常化を認めた．効果判定目的に造影 CT 

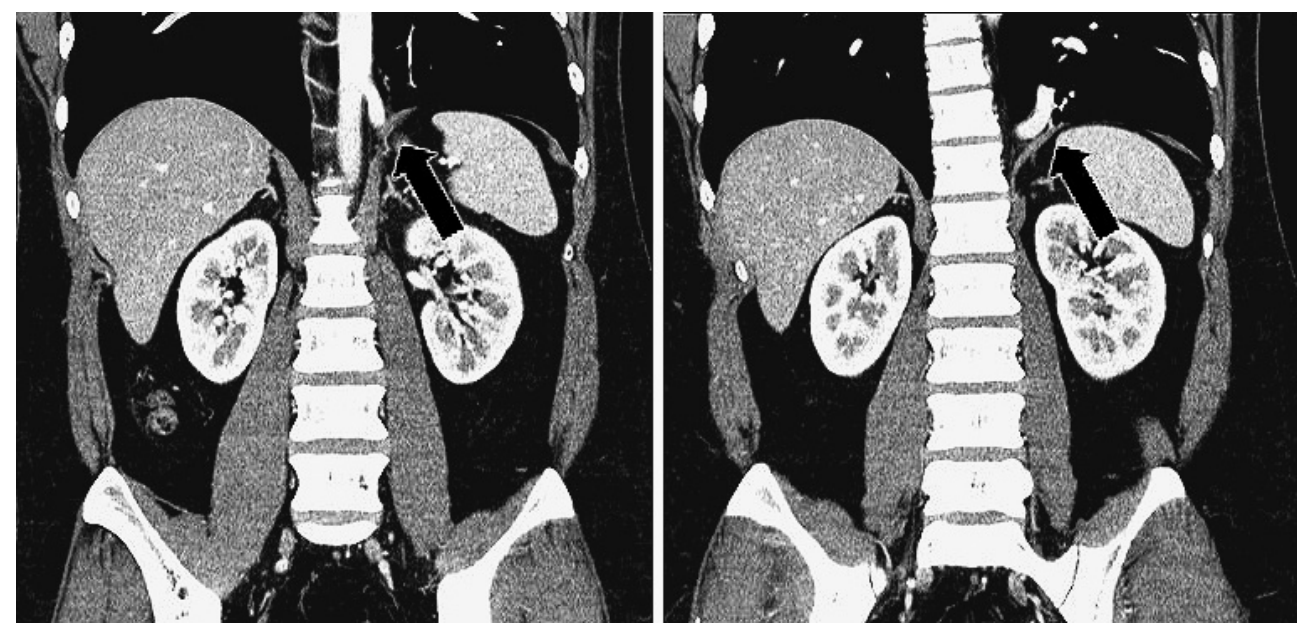

Fig. 1 An aberrant artery (feeding artery) derived from the thoracic descending aorta (arrow).

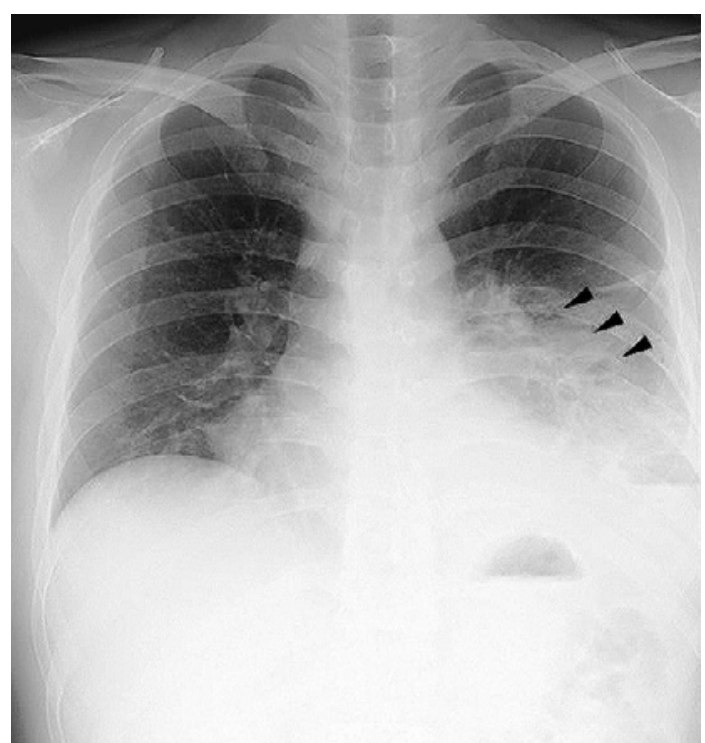

Fig. 2 A chest radiograph showed an abnormal shadow in the left lower field (arrow).

を施行したところ，分画肺内部は含気を認めず液体貯留 で置換されており，膿瘍腔の残存を認めた（Fig. 3b)．3 D 血管構築像では, 大動脈から分画肺に向かって分岐す る直径約 $12 \mathrm{~mm}$ の異常血管を認め, 前医の診断と一致し た (Fig. 3c)，肺内分画症であり今後炎症再燃の可能性も あるため, 手術を行う方針とした. 手術時期については, 内科的治療が奏功していたため, 待機的手術とすること も考慮した，しかし，膿瘍腔が残存している以上，炎症 の沈静化を完全に得るのは困難であり，炎症再燃を来し た場合切除がより困難になると考え, 発症より20日目に
施行した．術式は，炎症により分画肺と正常肺は強く癒 着していると考えられ，開胸への移行を想定したうえで 胸腔鏡下左下葉切除を予定した.

手術所見: 第 8 肋間中腋窩線に $2 \mathrm{~cm}$ の camera port を置き, 第 5 肋間前腋窝線に $3 \mathrm{~cm}$, 第 6 肋間肩甲骨下角 前方 $2 \mathrm{~cm}$ の皮切を加え, 各々 work port とした. 下葉背 側は軽度胸壁に癒着していたが，分画肺と横隔膜との間 に癒着を認めなかった。 上下葉間の分葉は良好であり， 肺門部の癒着も認めなかった．分画肺は硬く肥厚してお り，正常肺との境界は不明瞭であった，虚脱した状態で 観察したところ，正常肺部分が少なく，区域以上の正常 肺を残すことは困難と考えられ，予定通り胸腔鏡下下葉 切除を行う方針とした，下葉を頭側に毫引すると，横隔 膜に接して下行大動脈から分画肺に向かって分岐する動 脈を確認した (Fig. 4). Tri stapler ${ }^{\circledR}($ camel $45 \times 1)$ を用 いて切離した，その後, 通常通り肺動脈, 肺静脈, 気管 支を処理し，下葉切除を完遂した．下葉切除の操作にお いて，ほとんど出血は認めなかった，切除下葉は膿瘍の ために虚脱しなかったため, 前胸部創部を $5 \mathrm{~cm}$ に延長 したが，体外へ摘出する際に摘出肺からの血性廃液，排 膿を認めた，摘出後, 胸腔内を大量の生理食塩水で十分 に洗浄し，污染が無いことを確認し，手術を終了した。 手術時間は 3 時間 27 分であった. 出血量は摘出肺からの 廃液量を含め, $425 \mathrm{ml}$ であった。

切除標本：分画肺に向かって栄養動脈が流入していた (Fig. 5a).内部は多発囊胞状を呈しており, 黄色の膿汁流 出を認めた (Fig. 5b)，膿汁を細菌培養検査，抗酸菌検査 

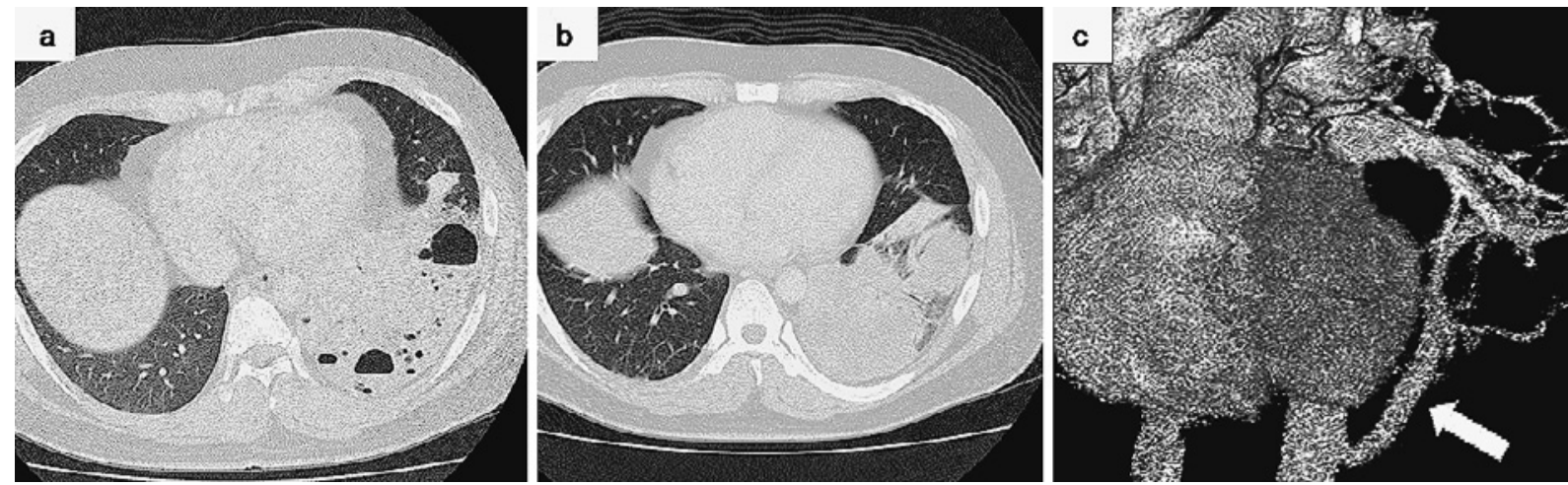

Fig. 3 a) Enhanced chest CT showed inflammation with a cavity in the left lower lobe.

b) Chest CT after chemotherapy showed that the cavity persisted.

c) 3D-CT demonstrated an aberrant artery from the thoracic descending aorta (arrow).

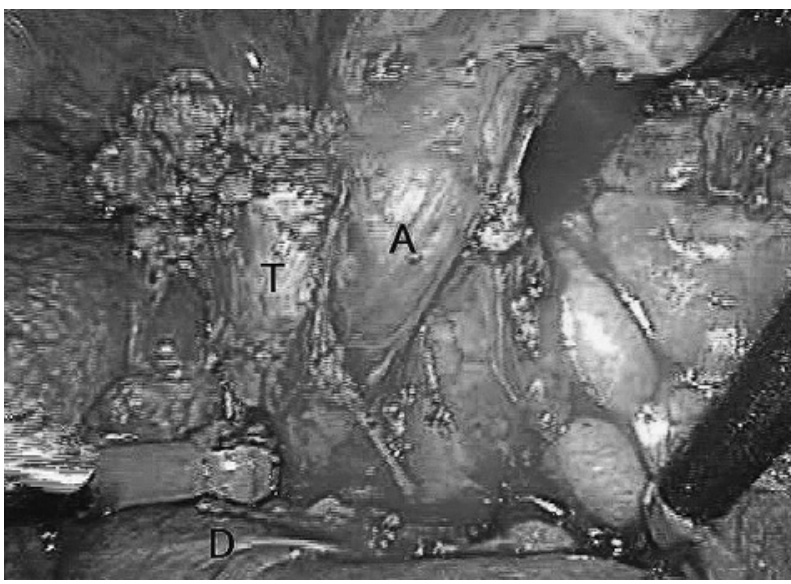

Fig. 4 Thoracoscopic findings: An aberrant feeding artery derived from the thoracic descending aorta. The sequestered lung was separated clearly from the diaphragm.

A: aberrant feeding artery, T: thoracic descending aorta, D: diaphragm

に提出したが，明らかな菌は検出されなかった．

病理組織学的所見：分画肺内の気管支は拡張し, 内腔 には，好中球，リンパ球から成る粘液眝留を認めた，分 画肺組織に悪性変化像を認めなかった，異常血管壁は肥 厚しており, 肺動脈と比較して弾性繊維成分が少なく, 大動脈由来のものと考えられた（Fig. 6a，b）.

術後経過：摘出標本に膿瘍残存を認めたため, 術後感 染予防目的に通常の CEZ に加えて PZFX を併用した。 経過は良好であり，術後 10 日目に退院となった (Fig. 7). 現在, 外来で経過を観察しているが, 症状再燃は認めて いない.
考察

肺分画症は，肺組織の一部が正常肺から隔離され， か つその部位が大循環からの血液供給を受けている肺の発 生異常である ${ }^{1,2)}$.

分画肺が正常肺と同じ胸膜で覆われる肺内分画症と正 常肺の外で独立した胸膜に覆われる肺外分画症に分類さ れる. そのうち肺内分画症は約 $75 \%$ を占め, 20 歳以上で 診断されることが多い. 肺外分画症は, 残りの $25 \%$ を占 め, 1 歳以下での発症が多く, 心血管系の発生異常などの 合併がみられる ${ }^{3,4)}$.

咳嗽，血痰，喀血，胸痛などの症状を初発症状とし， 肺炎などの炎症を繰り返すため，原則として手術治療が 適応となる ${ }^{3 \cdot 5}$.

本症例では，基礎疾患が肺分画症であったため，いず れかの時点で外科的切除は必要と考えられた。しかし， 内科的治療が奏功した場合の手術施行至適時期について の記載文献は無く, 手術時期の選択に非常に苦慮した。 内科的治療で感染や喀血のコントロールがつかず，早期 に手術に踏み切った報告はみられるが5.6)，手術時間や術 前の患者の状態を考慮すると非常に侵襲が大きいと思わ れる，そのため，当初は，抗生剤を長期間使用し，膿瘍 腔が消失してからの待機的手術を考慮した。しかし，画 像上で膿瘍腔が残存している以上，炎症再燃も危惧され た．炎症を繰り返す度に癒着が拡大することが予想され たため, 初回感染発症直後ではあったが, 手術を行った。 幸い胸壁への軽度の癒着は認めたが，分画肺と横隔膜と の間に癒着を認めず，流入動脈の同定，处理をスムーズ に行うことが可能であった。これは，発症早期に内科的 

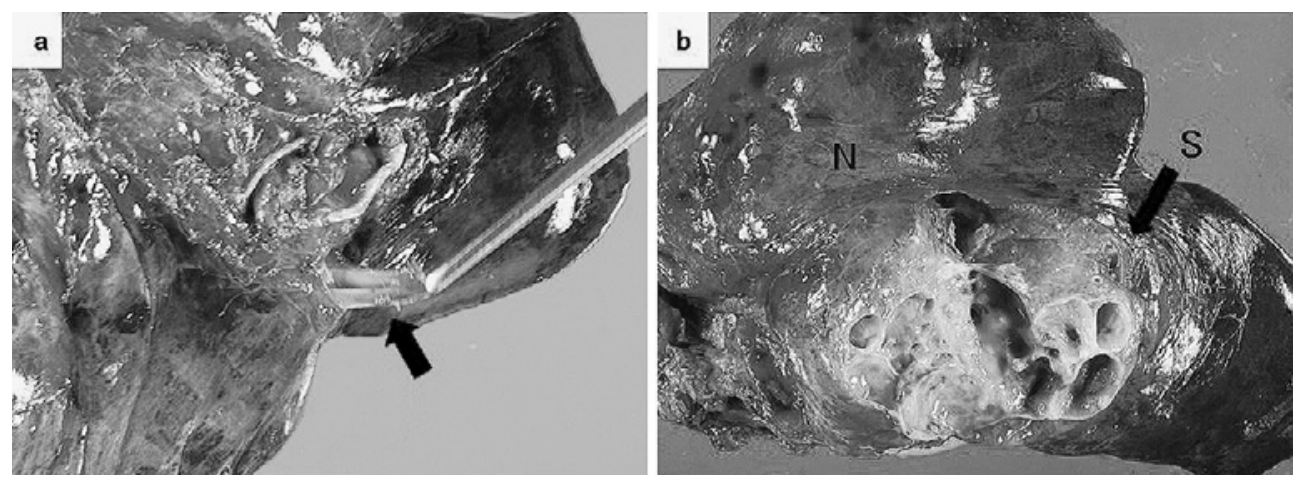

Fig. 5 a) The feeding artery was observed in the sequestered lung (arrow).

b) The border between the sequestered lung $(\mathrm{S})$ and normal lung $(\mathrm{N})$ was not clear.
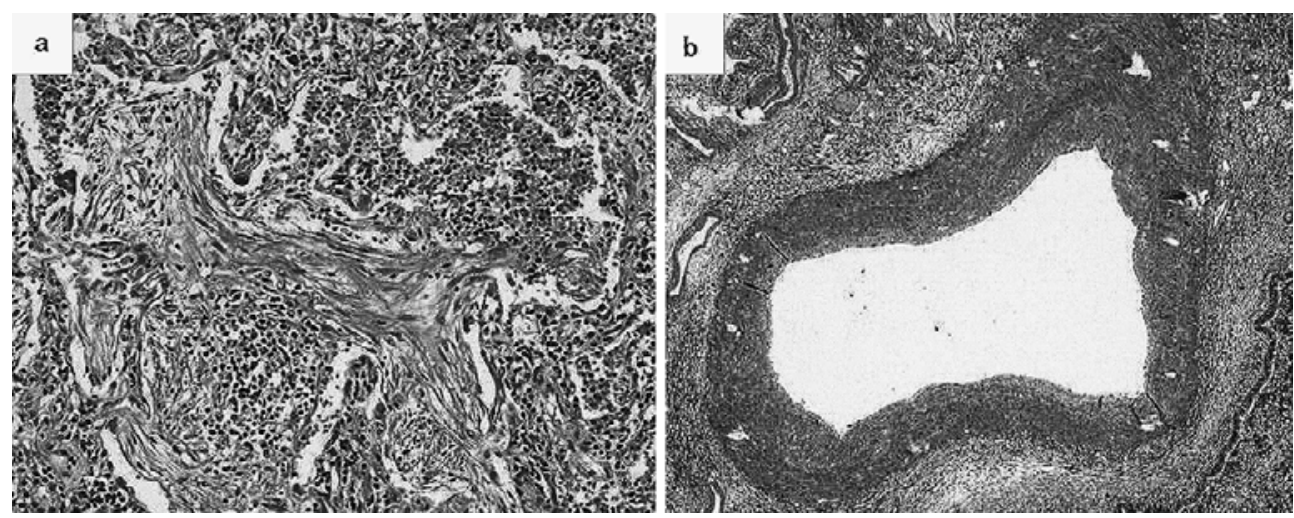

Fig. 6 a) Histological examination of the sequestered lung revealed a mucus-dilated bronchus. There was no malignant change. (H.E.stain, $\times 100$ )

b) An aberrant artery was found. (H.E.stain, $\times 20$ )
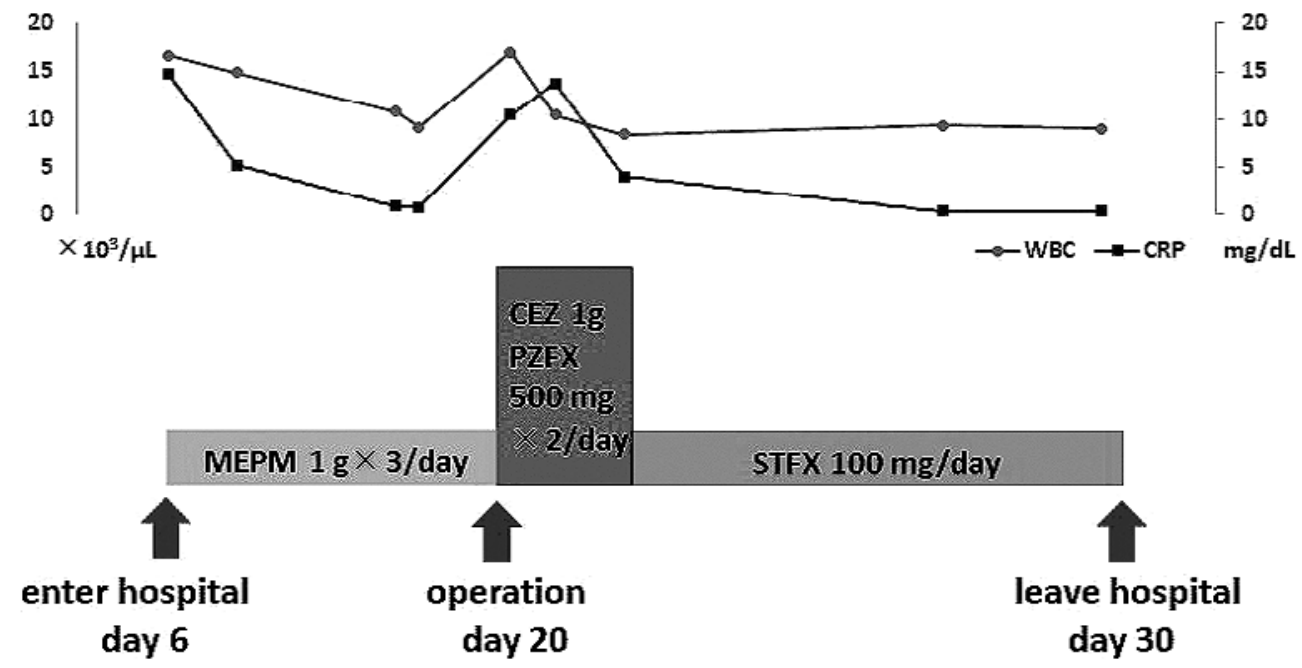

Fig. 7 Time line of treatments. 
治療を十分に行うことで胸膜まで炎症が波及せず, 周囲 組織への瘉着を最小限に抑えることが可能であったため と考える. 以上より, 肺分画症では何らかの症状を呈し た場合には内科的治療を可能な限り早期に行うこと, ま た, 内科的治療でコントロールが十分出来ている状態で あったとしても手術を早期に選択することが, 再燃した 場合のリスクを回避し, 低侵襲での根治的手術につなが る可能性が高いと考えられた。

また，近年では，胸腔鏡下手術が広く普及しており， 肺分画症に対する胸腔鏡下手術の報告も散見される ${ }^{3.5 .7)}$. 肺分画症の手術に拈いて, 流入動脈の同定と処理が最も 重要であると考える. 本症例では, 術前造影 CT で流入動 脈が明確に同定可能であった，また，その血管分岐が横 隔膜近傍であり, 更に膿瘍肺が十分に虚脱しない場合も 想定され, 胸腔鏡下のほうが開胸下より安全な視野確保 が可能と考え, 胸腔鏡下手術でのアプローチを選択した。 実際, 術中所見で, 胸壁周囲の軽度の癒着のみであり, 血管処理は安全に施行出来ると判断し, 最後まで胸腔鏡 下の操作のみで完遂することが可能だった．また，膿瘍 肺は虚脱せず, 狭いスペースでの操作が必要であったた め, 胸腔鏡を使用した視野確保は有効であったと思われ た. ただし, 胸腔鏡下手術に固執する必要性はないと考 える. 肺門部の癒着が強く, 血管処理が困難な場合には, 開胸手術へ移行すべきと思われる. 切除範囲については, 分画肺の摘出で十分と考えられ, 部分切除や区域切除の 報告も見られる ${ }^{4)}$. 一方, 分画肺の取り残しや正常肺との

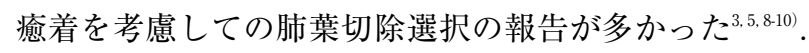
当初は, 呼吸機能温存を念頭に置いて, 分画肺のみの摘 出を目指したが, 分画肺と正常肺は境界が不明瞭であっ たため, 葉切除を行った. 術後の空気漏や炎症再燃の危 険性を考慮すると, 本症例においては, 葉切除が妥当で あったと思われた。

流入動脈の処理に関しては様々な意見がある．自動縫 合器を用いた異常動脈処理において合併症を認めなかっ たという報告も散見されるが8.11), 切除断端が動脈瘤化す る ${ }^{7)}$ という意見もある. 長期成績や報告は無く, 本症例で
も今後の厳重な経過観察が必要と思われる。

\section{利益相反}

本論文について申告する利益相反はない.

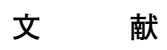

1. Pryce DM. Lower accessory pulmonary artery with intralobar sequestration of lung. J Pathol Bacteriol 1946; 58: 457-67.

2. Pryce DM, Sellors TH, Blair LG. Interlobar sequestration of lung associated with an abnormal pulmonary artery. Br J Surg 1947; 35: 18-29.

3. 前田 愛, 山下素弘, 小森栄作, 澤田茂樹, 栗田 啓. 胸 胿鏡補助下に非定型的区域切除した肺分画症の 1 例。 日 呼外会誌 2009; 23: 97-100.

4. 三島 修, 深井 原, 横田良一. 胸哚鏡下に摘出した肺葉 内分画症の 1 例. 日呼外会誌 2003; 17:570-3.

5. 谷岡利朗, 田中浩一, 山上英樹. 肺葉内分画症に対する胸 腔鏡下肺葉切除術. 日呼外会誌 2013; 27: 477-82.

6. 岡川武日児, 宇佐美範恭, 岡阪敏樹, 川口晃司, 福本紘一, 横井香平、喀血と血胸を来し緊急手術を要した肺葉内肺 分画症の 1 例. 日呼外会誌 2011; 25: 723-6.

7. 野口未紗, 奥村典仁, 中野 淳, 山科明彦, 松岡智章, 亀 山耕太郎．分画肺内に非結核性抗酸菌症を合併した肺葉 内肺分画症の 1 例. 日呼外会誌 2013; 27: 832-6.

8. 今給黎尚幸, 大㴊俊朗, 濱中和嘉子, 吉田康浩, 宮原 聡, 柳澤 純, 他. 肺分画症に対する外科治療 15 例の検討. 日呼外会誌 2011; 25: 595-9.

9. 田中聖子, 尾関雄一, 阪野孝充, 榊原史啓, 服部有俊, 亀 田光二，他. 胸哚鏡補助下に切除した肺葉内肺分画症の 1 例. 埼玉医会誌 2007; 42: 325-8.

10. 上林孝豊，鈴木 卓. 肺葉内肺分画症に対する分画肺切 除. 胸部外科 2011; 64: 1082-5.

11. Kestenholz PB, Schneiter D, Hillinger S, Lardinois D, Weder W. Thoracoscopic treatment of pulmonary sequestration. Eur J Cardiothorac Surg 2006; 29: 815-8. 


\title{
A case of thoracoscopic lobectomy for intralobar pulmonary sequestration
}

\author{
Mariko Aoyama, Takanori Miyoshi, Seiya Inoue \\ Naoki Hino, Masaru Tsuyuguchi \\ Department of Surgery, Tokushima Municipal Hospital
}

We report a case of intralobar pulmonary sequestration treated by thoracoscopic lobectomy.

The patient was a 30-year-old man. He consulted the hospital for fever, arthralgia, and general fatigue. He was diagnosed with intralobar pulmonary sequestration and empyema based on CT, and consulted us for treatment.

He received MEPM therapy. After chemotherapy, the symptoms disappeared, but chest CT showed persistent inflammation with a cavity. We perfomed thoracoscopic left lower lobectomy. He was discharged after 10 days. An early operation after the first infectious disease for intralobar pulmonary sequestration is safe and useful.

(C) The Japanese Association for Chest Surgery (JACS) 